\title{
Temperature and Time Model for Optimum Nutritional Contents in Soymilk Processing
}

\author{
Faith Uchenna Babalola and Oluwatobi Emmanuel Fajoye
}

\section{ABSTRACT}

Soybean is gaining wider acceptability as a cheap source of protein for human consumption and is therefore fast becoming a strong competitor with conventional (cow) milk. The challenge of undetermined standard cooking temperature and time was addressed using a statistical design software for Design of Experiment, analysis of results, derivation of mathematical models and optimization analysis. The optimization model maximized protein, carbohydrate, fat, and fibre while minimizing moisture and ash at the optimum cooking temperature of $118{ }^{\circ} \mathrm{C}$ and cooking time period of 30 minutes. The model was used to determine the optimum nutritional contents for six nutrients namely moisture $(\mathbf{8 8 . 4 9 0 \%})$, ash $(0.582 \%)$, fat $(0.928 \%)$, fibre $(1.459 \%)$, protein $(3.698 \%)$, and carbohydrate $(4.843 \%)$. The model was further tested by carrying out the experiment at the determined optimum cooking conditions. The result gave a very close match for most of the nutrients.

Keywords: soymilk, cooking variables, statistical Model, Nutritional content.

Published Online: March 26, 2021

ISSN: $2684-5199$

DOI: $10.24018 /$ ejbio.2021.2.2.163

Faith Uchenna Babalola*

Department of Chemical and Petroleum Engineering, University of Lagos, Nigeria.

(e-mail: fu_babalola@yahoo.com)

Oluwatobi Emmanuel Fajoye

Department of Chemical and Petroleum

Engineering, University of Lagos, Nigeria.

*Corresponding Author

\section{INTRODUCTION}

Soybean (Glycine max) has become one of the world's largest grain products in recent times. Over 284 million metric tons per annum of soybeans are produced globally [1]. Though soybean is native to eastern Asia and has been part of the main diets there for thousands of years, it has presently spread to other parts of Asia, North and South America and many parts of Africa. Asians eat soybeans whole after heavy processing while soy products, which include soymilk, soy sauce, soybean oil, soy flour and soy protein, are more common in other countries. In its raw form, soybean is used as animal fodder but is fast becoming more popular as a protein meal for humans [2]. The challenge of antinutritional factors (NAFs) in soybeans has come into focus and has been addressed by researchers leading to various thermal processes [3], [4]. Soybean is currently one of the most economical and important beans in the world providing protein for millions of consumers Soymilk is a rich creamy liquid extract of soybean, which resembles cow milk (conventional milk) in both appearance and consistency [5].

Soybeans are among the best sources of plant-based protein. Boiled soybeans contain about $17 \%$ protein, $10 \%$ carbohydrate, $3 \%$ sugar, $6 \%$ fibre, $9 \%$ fat and $55 \%$ water by weight. On a dry weight basis, the protein content of soybeans is $36-56 \%$ [6]. The nutritional value of protein from soybeans is good although not as high in quality as animal protein. Soybean's proteins are mainly glycinin and conglycinin which make up about $80 \%$ of the total proteins but may cause allergic reactions in some people. Interestingly, consumption of soy proteins has led to modest decrease in cholesterol levels [7].

A very popular soybean product is soymilk which contains as much as $3.50 \%$ protein, $2.00 \%$ fat, $0.50 \%$ ash, and $2.90 \%$ carbohydrate [2]. Soymilk has lower fat content than cow milk and contains no cholesterol. A nutritional comparison of cow milk with soymilk showed a close nutritional gap between them [8], [9]. Results of the proximate composition of the samples showed significant differences only in crude fat $(4.20 \%$ and $2.10 \%)$ and fibre contents (nil and 2.40\%) for cow and soymilk samples, respectively. However, other nutritional parameters such as moisture content $(85.0 \%$ and $84.5 \%)$, protein content $(5.70 \%$ and $6.00 \%)$, and carbohydrate content $(3.50 \%$ and $4.80 \%$ ) had very close comparable values (in cow milk and soymilk respectively). It has therefore been advocated that cow milk production should be substituted with soymilk production, where cow milk is relatively scarce and expensive.

Soymilk, if not adequately processed, would possess a characteristic flavour (beany flavour) due to the action of a soybean enzyme, lipoxygenase, which reacts with the unsaturated fatty acids in the oil in the presence of water and oxygen. This process is called autoxidation and results in hydro peroxides that are subsequently broken down to form aldehydes and ketones with strong odours and flavours, thus making the soymilk organoleptically unacceptable to consumers [10]. 
The acceptability of soymilk is also impacted by several anti-nutritional factors (ANFs) that are present in variable amounts in different species of raw (unprocessed) soybean. These ANFs consist mainly of heat-abile (trypsininhibitors, lectins, goitrogens and phytates) as well as heat-stable (oligosaccharides) factors [11]. Several hydrothermal and thermal processes aimed at achieving higher nutritive contents and removal of ANFs have been reported and include cooking [12], dry heating, toasting [13], infrared heating, autoclaving [14], and blanching [15].

Cooking as a thermal process is a simple and suitable approach to soymilk production. Mangaraj and Giri [16] classified the different cooking process methods for the production of soymilk into two namely: the traditional method and the modern method. The lack of standard cooking conditions (temperature and time) to obtain the optimal nutritional content of soymilk is a challenge faced by soymilk processors and is addressed in this paper. Niyibituronsa et al. [17] investigated the effect of different processing methods on the nutritional contents of soymilk. These methods include soaking soybeans in water for $12 \mathrm{~h}$ prior to milk extraction, blanching in NaHCO before extraction and soaking in $\mathrm{NaHCO}$ solution for $16 \mathrm{hrs}$ and subsequent cooking prior to extraction. Their findings revealed that soaking the soybean in water for $12 \mathrm{hrs}$ prior to milk extraction yielded the highest nutritional content compared to the other processing methods.

Ikya et al [10] observed that increase in cooking temperature from $80{ }^{\circ} \mathrm{C}$ to $110^{\circ} \mathrm{C}$ with a constant cooking time of 30 minutes resulted in an increase in the nutritional quality of soymilk while Orhevba [18] showed that the nutritional value of soymilk increased with increase in cooking time at a constant temperature of $100{ }^{\circ} \mathrm{C}$ and suggested that the appropriate cooking time for a safe and acceptable soymilk should be in the range of 20-30 minutes. This paper addresses the development of an experimental model using a statistical software (Design Expert) for the optimum nutritional value of soymilk with cooking temperature and cooking time as variables.

\section{MATERIALS AND METHODS}

The soybean used as the raw material for the production of soymilk was purchased from Mushin market, Lagos State, Nigeria. It was transported to the lab under ambient temperature in a polypropylene bag. The design of experiment (DOE) was done with the Design Expert version 10.0, using the central composite design (CCD), with two variables (cooking temperature and cooking time) and six responses as the nutritional contents (moisture, fibre, protein, carbohydrate fat and ash).

\section{A. Design of Experiment (DOE)}

In this work the experiment was designed using the Design Expert software package to evaluate the relationship between the parameters (cooking temperature and cooking time) and the output (nutritional contents). A Central Composite Design (CCD) package was used by inputting the lowest temperature of $60{ }^{\circ} \mathrm{C}$, highest temperature of $150{ }^{\circ} \mathrm{C}$, lowest time of 5 minutes and highest time of 30 minutes as the parameters and this generated a Design of
Experiment (DOE) output with 13 runs as shown in Table I. The design included some repetition of samples (B2 I - B2 V) which served to estimate the variability of the samples and hence increase the accuracy of the analysis and results.

\section{B. Preparation of Soymilk}

Extraction of soymilk was carried out by the simple traditional method of milk extraction as described by Mangaraj and Giri [16]. $1 \mathrm{~kg}$ of soybean was cleaned, soaked in water in a volume ratio $1: 3$ for $18 \mathrm{hrs}$, this supposes to remove the bitter taste. The soybean was washed with clean water, dehulled and wet-ground with hot water in a volume ratio $1: 8$ and filtered from its fibre (residue) using a muslin cloth.

\section{Cooking of the Extracted Soymilk}

The extracted soymilk was divided into 3 portions and marked as Samples A, B and C. Each portion was poured into a beaker, immersed in a water bath and cooked at $60{ }^{\circ} \mathrm{C}$ for Sample A, $105{ }^{\circ} \mathrm{C}$ for Sample B and $150{ }^{\circ} \mathrm{C}$ for Sample C. The samples were further divided and cooked for $5,17.5$ and 30 minutes as determined in the DOE (Table I). A thermometer and a stopwatch were used to regulate the cooking process variables.

These samples were marked with Numbers 1, 2, and 3 for cooking time 5, 17.5 and 30 minutes respectively. For example, the sample cooked at $60{ }^{\circ} \mathrm{C}$ for $5 \mathrm{mins}$ was labelled A-1 on the sample bottle. For repeated samples, they were labelled with Roman numerals. For example, the sample cooked at $105^{\circ} \mathrm{C}$ for 17.5 mins was labelled B-2I, B2II... B-2V as shown in Table I.

\begin{tabular}{cccc}
\multicolumn{3}{c}{ TABLE I: SOYMILK SAMPLES WITH THEIR COOKING VARIABLES } \\
\hline S No. & Sample & $\begin{array}{c}\text { Cooking } \\
\text { Temperature }\left({ }^{\circ} \mathrm{C}\right)\end{array}$ & $\begin{array}{c}\text { Cooking Time } \\
(\mathrm{mins})\end{array}$ \\
\hline 1 & A1 & 60 & 5 \\
2 & A2 & 60 & 17.5 \\
3 & A3 & 60 & 30 \\
4 & B1 & 105 & 5 \\
5 & B2 I & 105 & 17.5 \\
6 & B2 II & 105 & 17.5 \\
7 & B2 III & 105 & 17.5 \\
8 & B2 IV & 105 & 17.5 \\
9 & B2 V & 105 & 17.5 \\
10 & B3 & 105 & 30 \\
11 & C1 & 150 & 5 \\
12 & C2 & 150 & 17.5 \\
13 & C3 & 150 & 30 \\
\hline
\end{tabular}

After the cooking process the labelled samples were stored in a refrigerator at $4{ }^{\circ} \mathrm{C}$ to $8{ }^{\circ} \mathrm{C}$ for not more than $4 \mathrm{hrs}$ before analysis. A Proximate Analysis was carried out on each sample and the results were inputted into the response column of the Design-Expert Software to give an analysed result and thence generate a mathematical model for the optimal cooking temperature and time with the best desired value for each nutritional content.

\section{Proximate Test}

Food analysis procedures, adopted from the official methods of analysis of AOAC, 2005.08 [19], were used in the determination of the nutritional contents namely: moisture, protein, fat, fibre, ash, and carbohydrate. 


\section{E. Design Expert Software}

This is a statistical software that was used in performing the Design of Experiment (DOE), data analysis, derivation of the experimental models and Optimization analysis.

\section{RESULTS AND DISCUSSION}

The results obtained from the proximate analysis carried out on the soymilk cooked at different temperatures and for different time periods (Sample A1-C3) are presented in Table II. The values in Table II are shown as plots in Fig. 1 for clarity and easy comparison with the percentage moisture content divided by 100 to allow for visible superimposition on the same graph.

The purpose of Fig. 1 is to observe the trend of each nutrient as temperature increased from $60{ }^{\circ} \mathrm{C}$ (in the ' $\mathrm{A}$ ' samples), through $105^{\circ} \mathrm{C}$ (in the ' $\mathrm{B}$ ' samples) to $150{ }^{\circ} \mathrm{C}$ (in the ' $\mathrm{C}$ ' samples). It is also clearer to observe the trend of each nutrient within each sample set as cooking time increased. The moisture content percentage shows an infinitesimal decrease with increase in cooking temperature due to evaporation of water as cooking progressed. The value obtained varied between $94.01 \%$ and $87.20 \%$, and they fall within the range reported by Ikya et al. [10].

TABLE II: NUTRITIONAL COMPOSITION OF SOYMILK SAMPLES WITH COOKING VARIABLES

\begin{tabular}{|c|c|c|c|c|c|c|c|c|}
\hline Sample & $\begin{array}{c}\text { Cooking } \\
\text { Temperature }\left({ }^{\circ} \mathrm{C}\right)\end{array}$ & $\begin{array}{c}\text { Cooking } \\
\text { Time (mins) }\end{array}$ & Moisture (\%) & Ash (\%) & Fat $(\%)$ & Fibre $(\%)$ & $\begin{array}{c}\text { Protein } \\
(\%)\end{array}$ & Carbohydrate (\%) \\
\hline A1 & 60 & 5 & 94.01 & 0.51 & 2.48 & 0.43 & 2.5 & 0.07 \\
\hline $\mathrm{A} 2$ & 60 & 17.5 & 92.85 & 0.53 & 2.17 & 0.45 & 3.39 & 0.61 \\
\hline A3 & 60 & 30 & 91.69 & 0.54 & 1.86 & 0.49 & 3.42 & 2 \\
\hline B1 & 105 & 5 & 89.99 & 0.57 & 1.77 & 1.29 & 3.93 & 2.45 \\
\hline B2 I & 105 & 17.5 & 89.89 & 0.59 & 1.46 & 1.35 & 3.96 & 2.75 \\
\hline B2 II & 105 & 17.5 & 89.86 & 0.58 & 1.47 & 1.34 & 3.99 & 2.76 \\
\hline B2 III & 105 & 17.5 & 89.84 & 0.58 & 1.48 & 1.37 & 3.98 & 2.75 \\
\hline B2 IV & 105 & 17.5 & 89.88 & 0.59 & 1.45 & 1.39 & 3.98 & 2.71 \\
\hline $\mathrm{B} 2 \mathrm{~V}$ & 105 & 17.5 & 89.83 & 0.6 & 1.43 & 1.35 & 3.79 & 3 \\
\hline B3 & 105 & 30 & 89.19 & 0.61 & 1.15 & 1.56 & 4.02 & 3.47 \\
\hline $\mathrm{C} 1$ & 150 & 5 & 87.51 & 0.54 & 0.97 & 1.1 & 3.21 & 6.67 \\
\hline $\mathrm{C} 2$ & 150 & 17.5 & 87.4 & 0.52 & 0.66 & 1.02 & 2.95 & 7.45 \\
\hline C3 & 150 & 30 & 87.2 & 0.5 & 0.35 & 0.98 & 2.5 & 8.47 \\
\hline
\end{tabular}

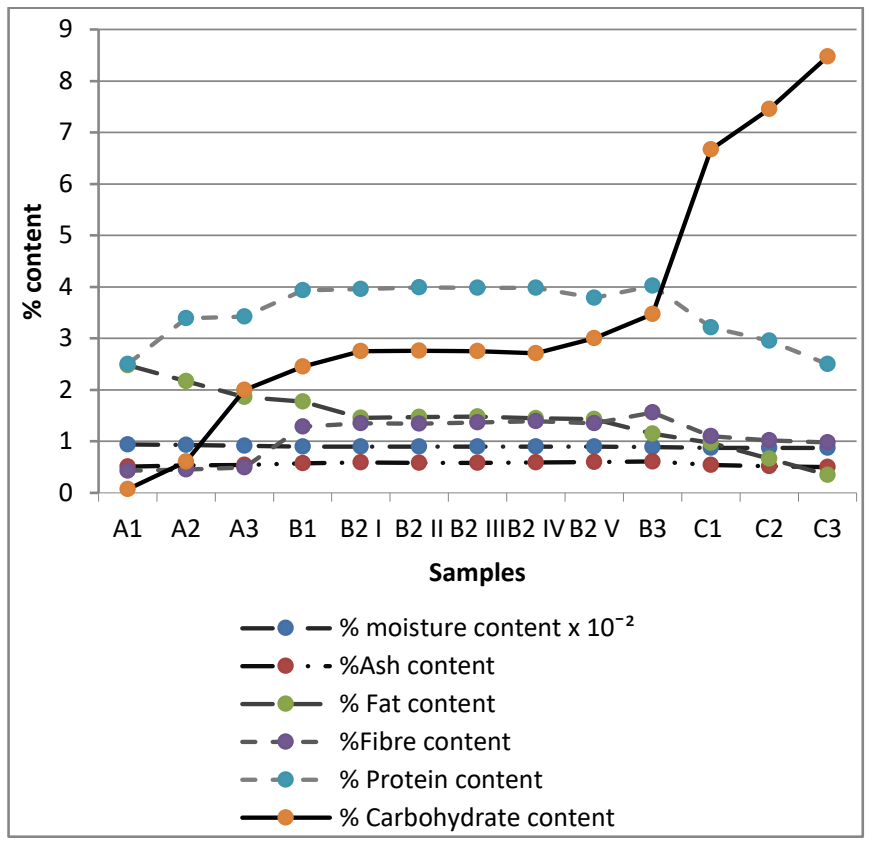

Fig. 1. Profiles of the nutritional contents of the soymilk in the samples.

Also, there is a decrease in the percentage of fat from 2.48 to 0.35 which could be due to temperature increase as well as increase in cooking time. The moisture and fat contents decreased while protein, fibre and carbohydrate contents increased with increase in temperature and time resulting in an improvement in the nutritional value of the soymilk. Looking more closely, it can be seen that the results obtained for the ash, fibre and protein contents show an increase in samples A1 to B3 and a decrease with samples cooked at $150{ }^{\circ} \mathrm{C}(\mathrm{C} 1-\mathrm{C} 3)$ as time increased. This shows that these nutrients get denatured at higher temperatures. The carbohydrate percentage shows an increase with increase in temperature. This is as a result of the AOAC official method of analysis [19] used in the determination of the carbohydrate percentage which is given in (1). Hence, any increase or decrease in the other nutrients would result in a corresponding decrease or increase on the value obtained for carbohydrate content.

$$
\begin{aligned}
& \text { Carbohydrate }(\%)=100-(\text { moisture } \%+\text { fat } \%+\operatorname{protein} \%+ \\
& \operatorname{ash} \%)
\end{aligned}
$$

An increase in carbohydrate content implies an increase in calories [14]. The result obtained (Table II) was analysed using analysis of variance (ANOVA) to determine the experimental model and its statistical significance (Prob < 0.05 ) using the nutritional content (output variables) and the operating parameters (input variables). The mathematical models derived are given in (2) to (7) while the 3D graphical representations are shown for the maximized nutrients (protein fat fibre and carbohydrate) in Fig. 2 and for the minimized nutrients (moisture and ash) in Fig. 3.

Moisture content $=100.45931-0.11639 \mathrm{~A}-0.10582 \mathrm{~B}+$ $8.93333 \times 10^{-4} \mathrm{AB}+1.89868 \times 10^{-4} \mathrm{~A}^{2}-9.6331 \times 10^{-4} \mathrm{~B}^{2}$

Ash content $=0.17707+7.22899 \times 10^{-3} \mathrm{~A}+3.70529 \times 10^{-3}$ $\mathrm{B}-3.11111 \times 10^{-5} \mathrm{AB}-3.21839 \times 10^{-5} \mathrm{~A}^{2}-1.10345 \times 10^{-6} \mathrm{~B}^{2}$

Fat content $=3.41660-0.012218 \mathrm{~A}-0.025032 \mathrm{~B}+$ $5.30687 \times 10^{-19} \mathrm{AB}-2.17114 \times 10^{-5} \mathrm{~A}^{2}+6.6206910^{-6} \mathrm{~B}^{2}$

Fibre content $=-2.95599+0.075125 \mathrm{~A}+2.0469 \times 10^{-3} \mathrm{~B}-$ $8.00 \times 10^{-5} \mathrm{AB}-3.20562 \times 10^{-4} \mathrm{~A}^{2}+2.61517 \times 10^{-4} \mathrm{~B}^{2}$ 
Protein content $=-2.35441+0.10502 \mathrm{~A}+0.10440 \mathrm{~B}-$ $7.24444 \times 10^{-4} \mathrm{AB}-4.51171 \times 10^{-4} \mathrm{~A}^{2}-6.95172 \times 10^{-4} \mathrm{~B}^{2}$

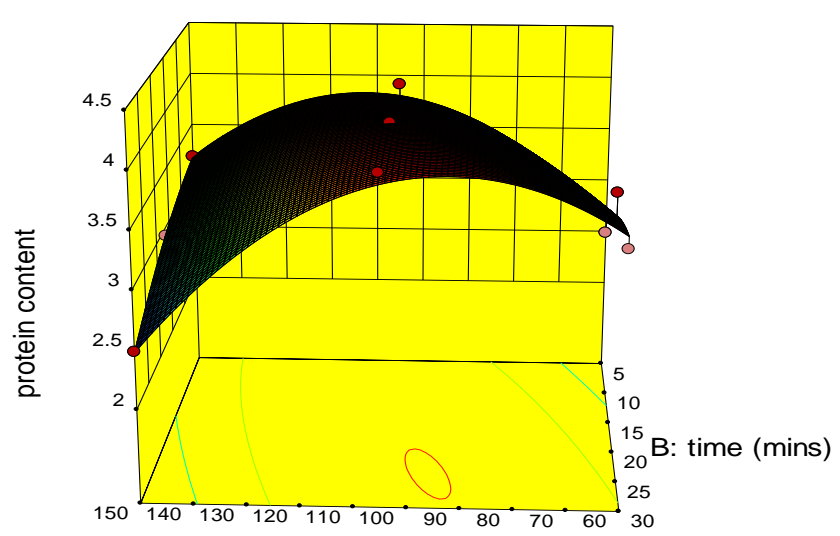

A: temp (oc)

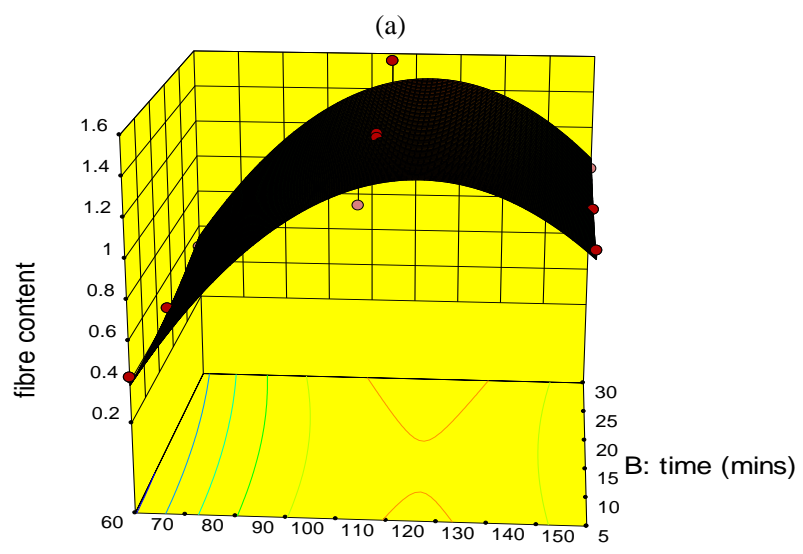

A: temp (oc)

(c)
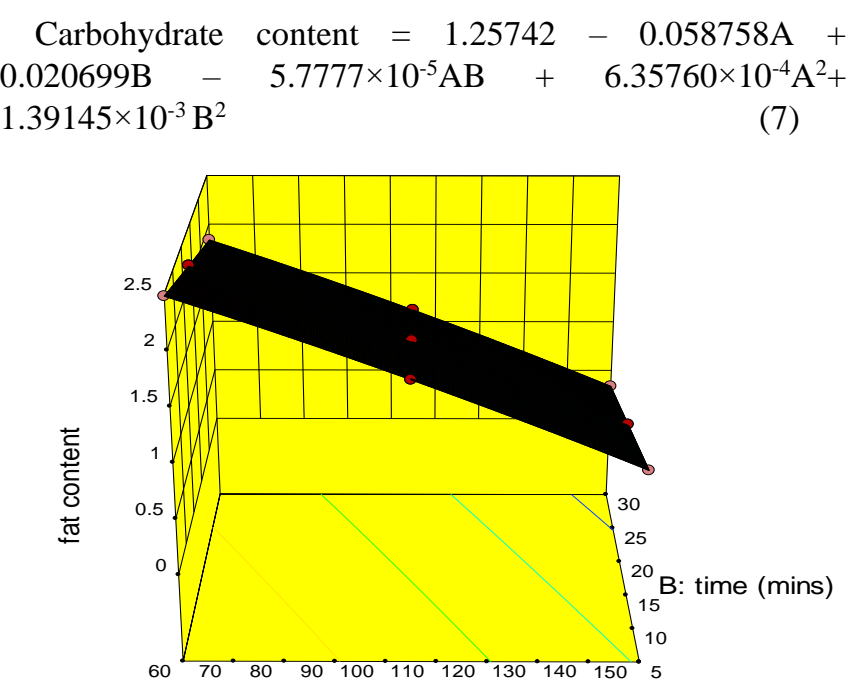

A: temp (oc)

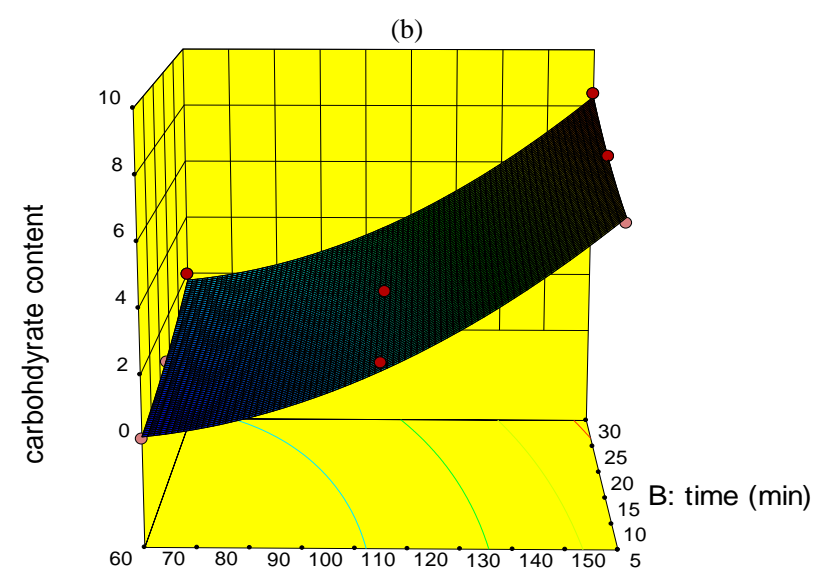

A: temp (oc)

(d)

Fig. 2. 3-D surface plots for the effect of cooking temperature and cooking time on the maximized nutrients (a) Protein (b) Fat (c) Fibre (d) Carbohydrate.

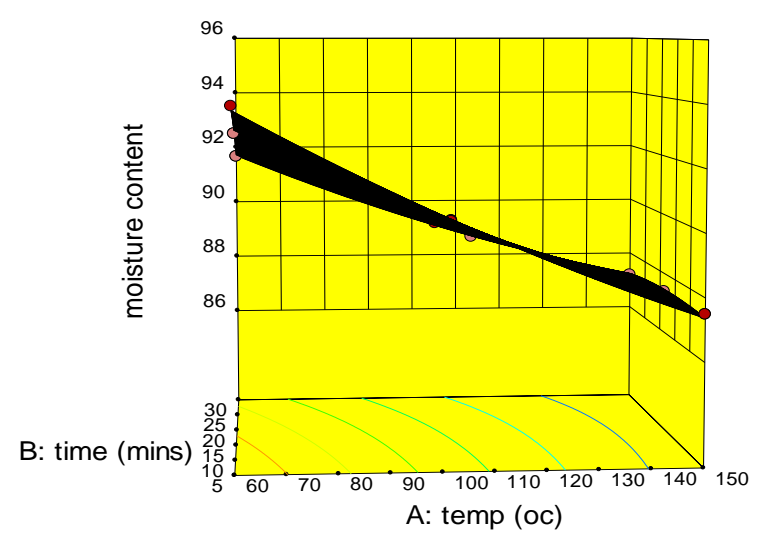

(a)

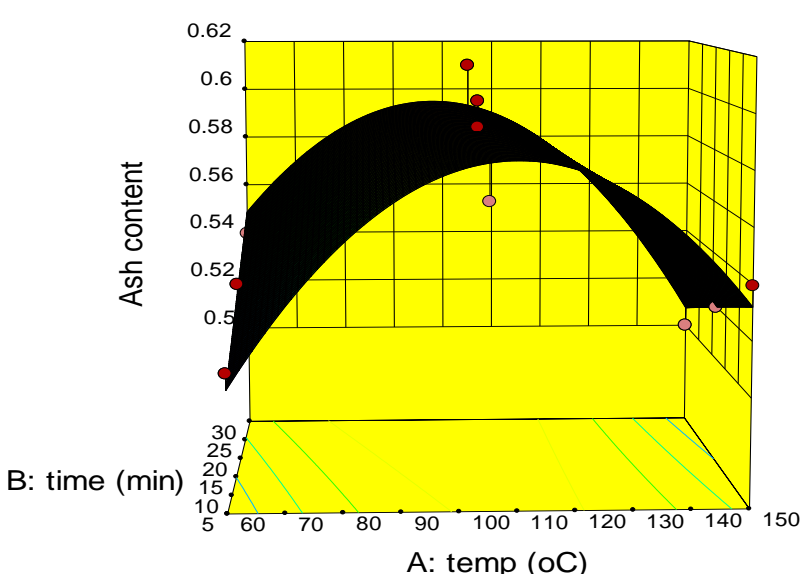

(b)

Fig. 3. 3-D surface plots for the effect of cooking temperature and cooking time on the minimized nutrients (a) Moisture (b) Ash.

Optimization analysis was carried out using Response Surface Methodology (RSM) with the analysis set to maximize fibre, protein, carbohydrate, and ash, and to minimize fat and moisture content for the soymilk using the Central Composite Design (CCD). The results obtained are shown in Table III. The optimal cooking temperature and time for soymilk to yield high protein, ash, fibre and carbohydrate contents, and low moisture and fat contents were obtained as $117.982 \approx \mathbf{1 1 8}^{\circ} \mathbf{C}$ and $\mathbf{3 0} \mathbf{~ m i n}$.
This agrees closely with the results obtained by Ikya et al. [10]. To experimentally test this model, a sample was prepared using the optimal cooking temperature $\left(118{ }^{\circ} \mathrm{C}\right)$ and cooking time (30 minutes) and a proximate test was carried out on it. The results were compared to the predicted values as shown in Fig. 4. 
TABLE III: SOLUTIONS TO THE OPTIMIZATION OBJECTIVE

\begin{tabular}{|c|c|c|c|c|c|c|c|c|c|}
\hline $\begin{array}{c}\text { Cooking } \\
\text { Temp }\end{array}$ & $\begin{array}{c}\text { Cooking } \\
\text { time }\end{array}$ & Water $\%$ & Ash\% & Fat $\%$ & Fibre $\%$ & Protein $\%$ & Carbohydrate\% & Desirability & \\
\hline 117.982 & 30.000 & 88.490 & 0.582 & 0.928 & 1.459 & 3.698 & 4.843 & 0.751 & Selected \\
\hline 118.004 & 30.000 & 88.489 & 0.582 & 0.927 & 1.459 & 3.697 & 4.845 & 0.751 & \\
\hline 118.573 & 30.000 & 88.464 & 0.581 & 0.918 & 1.457 & 3.684 & 4.897 & 0.751 & \\
\hline 118.967 & 30.000 & 88.446 & 0.581 & 0.911 & 1.456 & 3.674 & 4.932 & 0.751 & \\
\hline 119.625 & 30.000 & 88.417 & 0.580 & 0.899 & 1.453 & 3.658 & 4.992 & 0.751 & \\
\hline 119.982 & 30.000 & 88.401 & 0.579 & 0.893 & 1.452 & 3.649 & 5.025 & 0.750 & \\
\hline 114.392 & 30.000 & 88.653 & 0.586 & 0.990 & 1.465 & 3.775 & 4.530 & 0.749 & \\
\hline
\end{tabular}

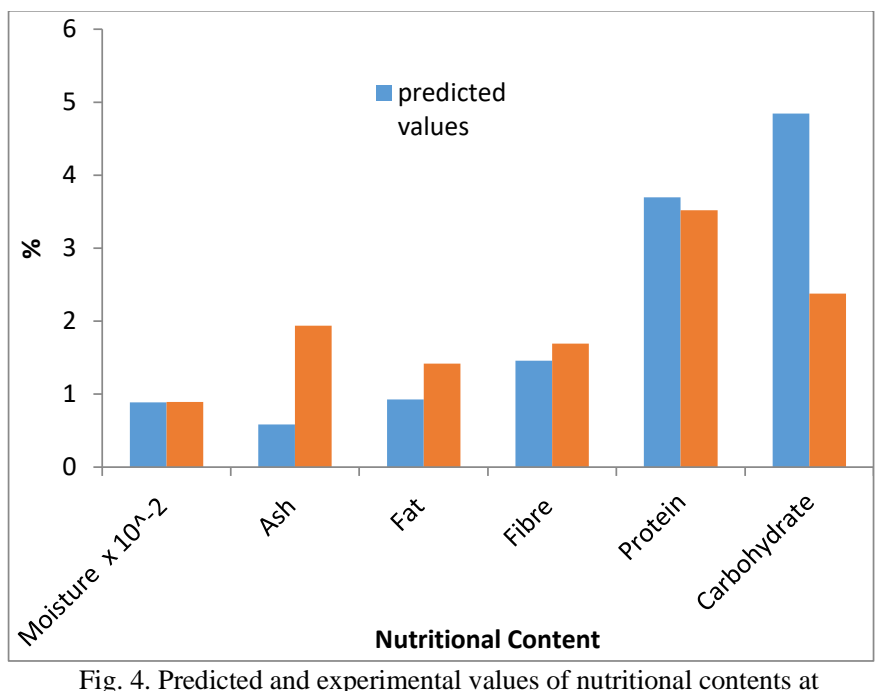

optimum Temp $\left(118^{\circ} \mathrm{C}\right)$ and optimum time (30 minutes).

The predicted and experimental values of the soymilk nutrients at optimum cooking temperature and time are shown in Fig. 4 but the relatively large moisture content value was divided by 100 for overall clarity and easy comparison. The values for moisture, fat, fibre and protein are quite close but significant variations were observed for ash and carbohydrate between the predicted and the experimental values obtained. This could be attributed experimental errors and the storage conditions of the raw soybean. The inference from these results is that a cooking temperature of between $115{ }^{\circ} \mathrm{C}$ and $120{ }^{\circ} \mathrm{C}$ and a cooking time of 30 minutes is adequate for optimum nutritional contents in soymilk production.

\section{CONCLUSION}

This study has shown that the key variables (cooking temperature and cooking time) for the cooking process during the production of soymilk for optimum nutritional contents can be determined using a computer software package for the design of experiment, analysis of experimental results and the derivation of the mathematical model for the optimum value of each nutrient.

In validating the model experimentally, a close match was observed between the predicted and the experimental values for protein (which is the nutrient of major concern here), fat, fibre and moisture. A significant gap was, however, observed for carbohydrate and ash which could be as a result of experimental errors. However, the predicted and experimental values are similar in their trends of nutritional contents.

It can therefore be concluded that the optimum nutritional content of soymilk can be obtained at cooking temperatures in the range of $115-120{ }^{\circ} \mathrm{C}$ and a cooking time of 30 minutes. At these conditions, there is no apparent defect in the nutritional value of soymilk.

\section{REFERENCES}

[1] Gaonkar, V., Rosentrater, K. A., Soybean in, Pan, Z., Zhang, R. and Zicari, S. (Eds.), Integrated Processing Technologies for Food and Agricultural By-Products. Academic Press, Elsevier Inc. Publ., Massachusetts, 2019, pp 73-104.

[2] Riaz, M. N., Soy Applications in Foods. CRC Press, Boca Raton, 2006 pp 275-286.

[3] Soetan, K. O., Oyewole, O. E., The need for adequate processing to reduce the anti-nutritional factors in plants used as human foods and animal feeds: A review, Afr. J. Food Sci., 3: (2009) 223.

[4] http://www.scielo.br/scielo.php?script=sci_arttext\&pid=S198470332013000300007\&lng=en (22.06.2020.)

[5] Williams, S., Akiko, A., Tofu' and Soy Milk Production. 3rd Edn., Centre, Lafayette, Californi, 2000, pp 1-17.

[6] Grieshop CM, Kadzere CT, Clapper GM, Flickinger EA, Bauer LL, Frazier RL, Fahey GC Jr. Chemical and nutritional characteristics of United States soybeans and soybean meals. J Agric Food Chem. 2003 Dec 17;51(26):7684-91. doi: 10.1021/jf034690c. PMID: 14664529.

[7] Young VR. Soy protein in relation to human protein and amino acid nutrition. J Am Diet Assoc. 1991 Jul;91(7):828-35. PMID: 2071798.

[8] Rehman, S., Nawaz, H., Ahmad, M. M., Hussain, S., Murtaza, A., Shahid, S. H., (2007). Physico-chemical and sensory evaluation of ready to drink soy-cow milk blend. Pak. J. Nutr., 6 (3) (2007) 283.

[9] Salau, R. B. Nutritional comparision of milk from two cow species and local preparation of soya milk drinks. Journal of applied chemistry, 6(2) (2012) 41.

[10] Ikya, J. K., Gernah, D. I., Ojobo, H. E., Oni, O. K., Effect of cooking temperature on some quality characteristics of soy milk, Adv. J. Food Sci. Technol 5(5) (2013) 543.

[11] Ari, M. M., Ayanwale, B. A., Adama, T. Z., Olatunji, E. A., Evalaution of the chemical composition and anti nutritional factors (ANFs) levels of different thermally processed soybeans, Asian J. Agric. Res. 6(2) (2012) 91.

[12] Destro, D., Bizeti, H. S., Marega-Filho, M., Morais, L. K., Tróia, C., Montalván, $R$., (2003) Genetic variability for traits related to cooking time in soybean, Crop Breeding and Applied Biotechnology 3 (4) (2003) 275.

[13] Tamiyu, L. O., 2001. Nutritive value of heat-processed full-fat soybeans (Glycine max) in diets for the African catfish (Clarius gartepinus) fingerlings. Ph.D. Thesis, Post Graduate school, Federal University of Technology, Minna, Nigeria 2001 11-39.

[14] Machado, F. P., Queiroz, J. H., Oliveira, M. G., Piovesan, N. D., Peluzio, M. C., Costa, N. M., Moreira, M. A., Effects of heating on protein quality of soybean flour devoid of Kunitz inhibitor and lectin. Food Chemistry, 107(2) (2008) 649. http://dx.doi.org/10.1016/j.foodchem.2007.08.061

[15] Yau-Chun, L. V., Huan-Lu, S., Xin, L., Liang, W., Shun-Tang, G., Influence of blanching and grinding with hot water on beany and nonbeany flavour in soy milk J. Food Sci., 76(1) (2011) 20.

[16] Mangaraj, S. K., Giri, S., Processing influences on composition and quality attributes of soymilk and its powder, Food Eng. Rev. (2012) 149.

[17] Niyibituronsa, M., Onyango, A. N., Gaidashova, S., Imathiu, S., Uwizerwa, S., Ochieng, E. P., Ng'ang'a, F. Birungi, J., Ghimire, S., Harvey, J., The effect of different processing methods on nutrient and isoflavone content of soymilk obtained from six varieties of soybean grown in Rwanda, Food Sci Nutr. (2018) 25;7(2) 457. doi: $10.1002 / \mathrm{fsn} 3.812$

[18] Orhevba, B. A., The effects of cooking time on the Nutritional parameters of soya milk.American Journal of Food Technology 6(4) (2011) 298. 
European Journal of Biology and Biotechnology www.ejbio.org

[19] Official Methods of Analysis of AOAC INTERNATIONAL $18^{\text {th }}$ Ed., AOAC INTERNATIONAL, Gaithersburg, MD, USA, Official Method 2005.08 32.2 pp27-49.

[20] Atti Amarson 2019 Soybeans 101: Nutrition Facts and Health Effects. https://healthline.com/nutrition/foods/soybeans.

[21] Anderson JW, Johnstone BM, Cook-Newell ME. Meta-analysis of the effects of soy protein intake on serum lipids. N Engl J Med. 1995 Aug 3;333(5):276-82. doi: 10.1056/NEJM199508033330502. PMID: 7596371.

[22] Ogawa A, Samoto M, Takahashi K. Soybean allergens and hypoallergenic soybean products. J Nutr Sci Vitaminol (Tokyo). 2000 Dec;46(6):271-9. doi: 10.3177/jnsv.46.271. PMID: 11227798. 